http://dx.doi.org/10.12775/szhf.2021.016

\author{
ZDEŇKA KALNICKÁ \\ University of Ostrava, Czech Republic \\ E-MAIL: ZDENKA.KALNICKA@OSU.CZ \\ ORCID: 0000-0001-6620-6763
}

\title{
The First Woman Philosopher with a Doctorate: Elena Cornaro Piscopia
}

\begin{abstract}
The study analyses the circumstances under which Elena Cornaro Piscopia became the first woman in the world to earn a Doctor degree in Philosophy, which she received from the University of Padua in 1678. The author presents the broader context of the outstanding accomplishment. She points out that, although universities did not allow women to enrol to study, Elena Cornaro managed to earn a doctorate thanks to several favourable circumstances. Of these, the author emphasises the tradition of intellectual centres at Renaissance courts in Italy, which were led by educated women-aristocrats; the development of the Venetian Republic in the sixteenth and seventeenth centuries, which affected the position of women, particularly those from aristocratic families; the openness of universities, namely the Universities of Padua and Bologna. Special attention is given to the family background, life, and studies of Elena Cornaro. The final part of the paper deals with other women philosophers of the seventeenth and eighteenth centuries.
\end{abstract}

Keywords: Venetian Republic, Doctorate in Philosophy, Elena Cornaro Piscopia, Laura Bassi, Maria Gaetana Agnesi, University of Padua, University of Bologna 


\section{University and a Woman - Antithesis?}

As medieval universities began to emerge, women were not allowed to enrol. The ban was probably never explicitly set in university regulations but stemmed from a shared belief in the "natural order of the sex", where the main task of the woman was to be wife and mother.

In addition, popular belief, supported by some of the philosophical and theological authorities (for example, Aristotle and Thomas Aquinas), rated women as inferior to men, both physically and mentally. ${ }^{1}$ Although educated women had lived in Europe throughout its history, with some winning recognition in philosophy, science, and the arts, the idea of an irreconcilable gap between the study of philosophy (science) and women persisted for centuries. The result was the above-mentioned attitude of the emerging top-level educational institution, namely the university, towards female students. Some universities began to open up to women in the mid-19th century, although it was only the end of the nineteenth century and the twentieth century that they were allowed to study at university on a larger scale (as a general principle). ${ }^{2}$ In history, there had been a few exceptions of women attending the university in some form (for example, Anna Maria van Schurman, discussed below in the text) or following the university curriculum at home - which was the case of Elena Cornaro.

Already Plato accepted women at his Academy, and according to Diogenés Laertius, two women, Axiothea and Lasthenia, studied at the school. ${ }^{3}$ His

1 See Aristotle, On the Generation of Animals, Bks. I, II. Visited 22.03.2020. http:// www.esp.org/books/aristotle/generation-of-animals/index.html; Aristotle, On the History of Animals, Bk. IX. Visited 22.03.2020. http://www.esp.org/books/aristotle/history-of-animals/ index.html; Aristotle. Politics, trans. Benjamin Jowett. Visited 22.04.2020. http://classics.mit. edu/Aristotle/politics.1.one.html, Thomas Aquinas, Summa Theologica, Part I, Question 92. trans. Fathers of the English Dominican Province. Visited 22.03.2020. https://www.documentacatholicaomnia.eu/03d/1225-1274,_Thomas_Aquinas,_Summa_Theologiae_\%5B1\%5D, EN.pdf.

2 For more on the gradual opening of official education to women around the world, see Girls' Secondary Education in the Western World: From the 18th to the 20th Century, eds. James C. Albisetti, Joyce Goodman, Rebecca Rogers (New York: Palgrave Macmillan, 2010).

3 See Diogenés Laertios, Lives of the Eminent Philosophers, transl. Pamela Mensch (Oxford: Oxford University Press, 2018). 
teacher, Socrates, himself also visited the salon of Aspasia, who apparently lectured him in the art of rhetoric. Socrates refers to himself in the Symposium as a disciple of Diotima of Mantinea, who bestowed on him the teachings of the nature of Erot, which he merely reproduces in his speech. ${ }^{4}$ Gilles Ménage found references to 56 women philosophers in ancient texts, as evident from his History of Women Philosophers written in $1690 .{ }^{5}$ It is a historical fact that women philosophers and scientists were active during European history, and sometimes more, sometimes less accepted. The 17th century in particular was rich in the philosophical achievements of women; the possible reason for that phenomenon will be mentioned later. Though, the period after the French Revolution consolidated the belief in the intellectual inferiority of women, and the division between "male" and "female" spaces and social roles became more rigid than ever before. Theoretical arguments supporting the idea of separate spheres in that time were supplied by Jean-Jacques Rousseau. His theory of the dual human nature attributed woman and man with different abilities (man - reason, activity, woman - emotion, passivity) and spaces (man - public sphere, woman - private sphere). ${ }^{6}$ However, it is not the goal of the present study to analyse philosophers' views on man's and woman's nature or provide a comprehensive overview of women philosophers in European history. ${ }^{7}$ The goal is to analyse the context that enabled Elena Lucrezia Cornaro to become the first woman in the world to receive a Doctor degree in Philosophy. This accomplishment is a fact, as the University of Padua

4 See Plato, The Symposium, transl. Christopher Gill (New York: Penguin, 2003).

${ }^{5}$ Gilles Ménage, The History of Women Philosophers, trans. Beatrice H. Zedler (Lanham: University Press of America, 1984).

6 See Jean-Jacques Rousseau, Emile, or On Education, trans. Allan Bloom (New York: Basic Books, 1979).

7 For introduction to the first problem, see for example Geneviève. Lloyd, The Man of Reason. "Male" and "Female" in Western Philosophy (Minneapolis: University of Minnesota Press, 1984); Nancy Tuana, The Less Noble Sex. Scientific, Religious, and Philosophical Conceptions of Woman's Nature (Indiana University Press, Bloomington and Indianapolis, 1993); or anthology History of Ideas on Woman: A Source Book, ed. Rosemary Agonito. For introduction to the second problem see A History of Women Philosophers, vols. I-IV, ed. Mary Ellen Waithe (Dordrecht: Kluwer Academic Publishers, 1987, 1989, 1991, 1994). 
contacted all the universities in the world in 1969 to verify Elena Cornaro's primacy; it was confirmed, and the result was published. ${ }^{8}$

Only the following of the circumstances which coincided to her benefit and allowed her success are analysed: the tradition of aristocratic Renaissance women who established intellectual centres at their courts; the free-spirited nature of the Venetian Republic and its universities; and above all, the life story of Elena Cornaro, where her father's support was a significant and positive factor. The paper concludes by placing Elena Cornaro into the broader context of women philosophers of the seventeenth century, and by raising the question of whether her case influenced the relationship of academic institutions to women's intellectual (philosophical and scientific) abilities.

\section{Intellectual Predecessors}

As indicated above, the history of Europe has seen a significant number of outstandingly educated women; however, they were considered "unfeminine" and deviant from the idea of the natural mission of a woman: to be primarily a mother and a wife. However, the Middle Ages were marked, particularly as the cult of the Virgin Mary spread, by a steep rise in the value of virginity, and numerous women decided to voluntarily (sometimes they were forced, as seen further in the text) sacrifice themselves to God and join a cloister to become a nun. These women viewed cloisters as a service to God and as a space for education and a life offering greater independence than that of married women. Nuns were, moreover, held in a higher esteem by society, in comparison to worldly women, as the former followed the example of the Virgin Mary, while wives were always stained by Eve's sin.

The intellectual (philosophical) women of Europe have often been overlooked by official historiography and thus forgotten. Research triggered by the second wave of feminism and focused on rediscovering the intellectual

${ }^{8}$ Francesco L. Maschietto, Elena Lucrezia Cornaro Piscopia (1646-1684) - The First Woman in the World to Earn a University Degree (Philadelphia: Saint Joseph's University Press, 2007), 137. 
achievements of women in the past, shows, however, that these women were often accepted and appreciated by the then society. ${ }^{9}$ The late Renaissance or the early modern period, which is when Elena Cornaro lived, often viewed these women as "miracle children" (prodigy), as they shone from an early age with outstanding intelligence and interest in learning. Supported by (mainly) their fathers, they were mostly educated at home by paid teachers, at court salons or through self-study. They often sought contact with other similar women around Europe, thus creating a virtual "city of women", a vision conveyed by Christina de Pizan (1364-1430) in her Book of the City of Ladies, published in $1405 .^{10}$

Concerning the intellectual predecessors of Elena Cornaro, we can mention Elena's ancestor, Catherine Cornaro, one of the prominent women of the Renaissance. The Cornaro family excelled in their interest in education, culture and the arts. The sons were educated in the tradition of Renaissance humanism, and many of them became prominent members of the literary salons of Venice in the early sixteenth century. A few women in the family apparently also received excellent education, as evident from the case of Catherine Cornaro (1454?-1510), who was educated from the age of ten in a monastic school run by Benedictine nuns in Padua. Catherina Cornaro married the king of Cyprus. Her husband died shortly after the wedding, and she ruled Cyprus for sixteen years, battling intrigues, coup attempts, and wars. After returning to Venice, she established a Renaissance court in Asolo (near Venice), where she became the patron of literature, art, and humanities. ${ }^{11}$ One of its members was Pietro Bembo, a prominent Italian human-

9 This topic is outside the scope of the present study; for more about the causes and context of this phenomenon, specifically with regard to the history of philosophy, see Zdeňka Kalnická, "Genderovanost filozofického kánonu a textové 'strategie' marginalizace filozofek", Sociologický časopis/Czech Sociological Review 45 (2009): 809-833.

10 See Christine De Pizan, The Book of the City of Ladies, trans. Rosalind Brown-Grant (London: Penguin Classics, 2000).

${ }_{11}$ Catherine Cornaro may have been the inspirer or patron of the renowned Aldine Press (Aldus Manutius), which published many of Aristotle's writings and the Greek writings of other ancient philosophers, and contributed to the development of high quality publishing in general. For more about the publishing house and its importance for the studies of Aristotle at the University of Padua, see Charles B. Schmitt, The Aristotelian Tradition and Renaissance Universities (London: Valorium Reprints, 1984). 
ist with close ties to the Academy of Florence, while in Asolo, he wrote his Gli Asolani. ${ }^{12}$ In the book, drawing on the intellectual life of the court under the patronage of Catherine Cornaro, Pietro Bembo maintains that women should be accepted as equal partners in the dialogue; they can acquire knowledge because they have a mind like men; if educated, they can achieve the same results. A bestseller of its time, Gli Asolani was translated into Spanish, French and English, and published in six versions in the sixteenth century. Bembo's experience of life at the Renaissance court of Catherine Cornaro and her personality helped to create the character of an educated Renaissance aristocratic woman, supporter and patron of science and art, which spread throughout Europe (thanks to the even more popular The Book of the Courtier written by Baldassare Castiglione ${ }^{13}$ ).

The tradition of educated Italian women dated back to the tradition of Roman matrons and was encouraged during the Renaissance by a number of philosophers (such as Pietro Bembo, Erasmus of Rotterdam) and writers (such as Giovanni Boccaccio, Baldassare Castiglione). This might be the reason why Italian universities were the only ones to make an exception from their very beginnings by accepting women students. ${ }^{14}$

Families in Italy, and aristocratic families in particular, traditionally offered education also to their gifted daughters, Elena Cornaro being one of them. Besides having been born in one of the leading aristocratic families in Italy, Elena Cornaro was also lucky in that she was born in Venice, a city with a specific character.

\section{The Republic of Venice and the Status of Aristocratic Women}

When Elena Cornaro was born, the Republic of Venice was nearly 900 years old. It was founded in the sixth or seventh century, became a maritime power by 1300 and a territorial power by 1400 . Venice acquired Padua and

12 The first edition was published in 1505 by Aldus Manutius.

${ }_{13}$ Baldassare Castiglione, The Book of the Courtier, trans. Leonard Eckstein Opdycke (New York: Dover Publications, 2003).

14 Mary Ellen Waithe, A History of Women Philosophers, vol. III, xviiii. 
Verona in 1405, and in 1454 it expanded its territory west to Bergamo and Crema (almost to Milan) and along the Adriatic coast to Dalmatia (Croatia). The Venetian Republic was threatened by a war in which France, Spain, and the Pope joined forces to fight it; survived the Reformation and the CounterReformation, yet remained relatively free and independent for almost a thousand years. Although its heyday was in the fifteenth and sixteenth centuries, it was still alive in the seventeenth century. It was brought to an end when Napoleon took possession of the city in $1797 .{ }^{15}$

The Republic of Venice was one of the most prosperous countries in Europe, and its unique government became a model for other countries. The Venetian islands were united into a single country ruled by an elected doge around the first millennium. The doge's power was reduced around the thirteenth century by a group of the most influential families known as the Great Council. It introduced the institution of hereditary succession of about 150 families (about 1,200 male members) with the exclusive right and duty to serve the state and have access to political power. They were listed in the Golden Book (Libro d'Oro della Nobilità Italiana). The Cornaro family belonged to this group, being one of the oldest, foremost, and wealthiest families in Venice and even one of the very founders of the Venetian Republic. Its (male) members held the most crucial state offices in the Venetian Republic; some were doges, cardinals, and members of the highest Republic authorities.

As the state suffered from the lack of funds, the Golden Book of Venice was opened in the seventeenth century to other families and family members who had been denied this privilege based on an origin deemed by the then standards as non-aristocratic (boys born out of wedlock or to an aristocratic husband and a middle-class wife). Now they could register themselves in return for a high fee. Elena Cornaro's father used this opportunity to have two of his sons, who had been born before his marriage (and whose mother was, on top of that, a non-aristocrat), registered in the Book. Although the social structure of Venice and the Venetian Republic changed over the years, it never faced such social upheavals as other Italian and European states,

15 For more on the history of the Republic of Venice, see John J. Norwich, A History of Venice (London: Vintage, 1971); John J. Martin, Dennis Romano, Venice Reconsidered: The History and Civilization of an Italian City-State, 1297-1797 (Baltimore: The Johns Hopkins University Press, 2002). 
and the output of its writers, poets, and artists were only rivalled by Florence and Rome. When the Inquisition was set up, Venice cooperated with it, but reserved the right to appoint its own officials responsible for examining religious heresy. Its "independence" and the limitation of the Pope's power protected the University of Padua and helped develop local medicine thanks to autopsies and local science thanks to experiments. The Republic of Venice and the rationalism and scepticism of its leaders, members of the Venetian Inquisition, also protected many women from witchcraft trials, which were a threat mainly to women in Europe of the fifteenth through seventeenth century. ${ }^{16}$

The careers of women in the Venetian Republic were similar to those in other parts of Europe at the time, with most women following the wife or nun "possibility" (there were also other groups of women, such as prostitutes). Women were expected to obey their fathers and, if married, their husbands, focusing on raising children and charity. Society placed an increased emphasis on female purity, either in the form of a life consecrated to God in cloisters and new orders, or at least marital moral purity. As Jutta G. Sperling documents, $60 \%$ of women from patrician Venetian families lived in cloisters in the late 16 th century. ${ }^{17}$ This was only partly due to the religious inclination of these women - many were placed here by their families or decided to come because their families could not afford their dowry, which had become so steep in Venice over the centuries that it was ruinous for many families. Another possible reason was Venetian custom which prevented aristocratic women from marrying below class, while men were free to take advantage of this option, although they risked, as seen above, that their sons would not be able to hold political office within the Venetian Republic. In addition, a number of aristocratic Venetian men remained single in order not to

16 As Duni writes, the Republic of Venice had zero witchcraft convictions out of over a hundred charges at the time of the Venetian Inquisition, the time of the Church's peaking enthusiasm to combat witchcraft, see Matteo Duni, Under the Devil's Spell: Witches, Sorcerers, and the Inquisition in Renaissance Italy (New York: Syracuse University Press, 2008), 31. For more information, see Jonathan Seitz, Witchcraft and Inquisition in Early Modern Venice (Cambridge: Cambridge University Press, 2011).

${ }_{17}$ See Jutta G. Sperling, Convents and the Body Politics in Late Renaissance Venice (Chicago: The University of Chicago Press, 2000). 
dilute inheritance, thus creating a shortage of partners for aristocratic women in Venice. ${ }^{18}$ Stanley Chojnacki, however, argues that, even though Venice was patriarchal in its strict separation of the public sphere for men and the private sphere reserved for women, "patterns of gender identity in the Venetian patriciate were flexible, offering at least a range of choice, for women and men". ${ }^{19}$ The next chapter reveals the choice Elena Cornaro made. ${ }^{20}$

\section{Elena Cornaro Piscopia}

Elena was born as the fifth child of Giovanni Battista Cornaro Piscopius and Zanetta Giovanna Boni. As mentioned above, Giovanni Battista Cornaro came from an old and wealthy aristocratic family - his grandfather Alvise Cornaro had built an enormous library, which Giovanni inherited as the only male descendant of the family. This library was one of the best private libraries of the time, and it was visited by many intellectuals and scientists from Venice and elsewhere. Giovanni loved and supported art, had a passion for studying, and was acquainted with numerous scholars of his time. The mother Zanetta Boni came from a plebeian family who had probably

18 For more on the position of women in the Republic of Venice, see Stanley Chojnacki, Women and Men in Renaissance Venice: Twelve Essays on Patrician Society (Baltimore: Johns Hopkins University Press, 2000) and Stanley Chojnacki, “The Most Serious Duty: Motherhood, Gender, and Patrician Culture in Renaissance Venice”, in Refiguring Woman: Perspectives on Gender and the Italian Renaissance, eds. M. Migiel, J. Schiesari (Ithaca: Cornell University Press, 1991), 133-154.

19 Chojnacki, "The Most Serious Duty: Motherhood, Gender, and Patrician Culture in Renaissance Venice": 153.

20 The following text draws on the most extensive biography of Elena Cornaro, written by Francesco Ludovico Maschietto, a Benedictine monk from the Abbey of Santa Giustina in Padua: Elena Lucrezia Cornaro Piscopia (1646-1684) - The First Woman in the World to Earn a University Degree. Published after eight years of research in 1978 in Italian, and in 2007 in English with multiple archival materials available in the appendix, the monograph is a fundamental and reliable source of information. The author reviews previous biographies and highlights some of the mistakes their authors made. Another substantial biography came out in 1999: Jane H. Guernsey, The Lady Cornaro, Pride and Prodigy of Venice (Wooster: College Avenue Press, 1999). 
immigrated to the Venetian Republic from another area of Italy (Brescia). Her father was probably a craftsman. The relationship was inadequate according to the then customs and threatened Giovanni Cornaro's good name. Zanetta gave Giovanni Cornaro five children (two sons and three daughters) before he married her - Elena Cornaro was also born illegitimate. They married only when Zanetta was pregnant with their sixth child, in 1654.

In 1649, three years after Elena was born, Giovanni Cornaro was appointed Supreme Procurator of Saint Mark and was in charge of the administration of all aspects of the St. Mark's Basilica. It was the second most prestigious public office after that of Doge of Venice.

Elena Cornaro began to study at the age of seven, being declared a miracle child by the local priest. Her father decided to give her the best possible education, allowed her to study books from his library, hired the best priests and professors to teach her languages, mathematics, philosophy (Carlo Rinaldini, professor of philosophy at the University of Padua), and theology (Felice Rotondi, professor of theology at the University of Padua). In addition to Italian, she spoke Latin, Greek, Hebrew, Arabic, Aramaic, French, English, and Spanish. She also studied mathematics, astronomy, geography, and other sciences. She was also an excellent musician. Aged seventeen, she played the clavichord, harpsichord, harp, violin, and composed music. Maschietto writes that the father supported his daughter in her studies also because he saw her success in this area as a way of improving the somewhat tarnished reputation of the Cornaro family (caused by his unequal marriage to Zanetta Boni) and restoring its glory and respect.

Elena Cornaro was very pious. Her deep religious beliefs were evidenced by the fact that she wanted to become a nun. Although her sister joined the convent, her father did not allow Elena to follow this path, apparently driven by the aforementioned plan to "use" her for his goal: to boost the credit of the Cornaro family. Elena Cornaro also rejected several marriage proposals, becoming in 1665, after thinking for a long time which order to link her religious life with, an oblate (lay nun) of the Benedictine order, which was based in the Basilica of Santa Giustina in Padua.

Elena Cornaro immersed herself the deepest in the study of theology and philosophy; she was taught philosophy by Carlo Rinaldini for ten years, between 1668 and 1678. Carlo Rinaldini was a close friend of Galilei while he 
taught at Pisa. He was a member of the renowned Accademia del Cimento, founded in Florence by the disciples of Galileo Galilei. He was also one of the first to lecture on Galileo's discoveries at the University of Pisa and later in Padua, where he moved and taught natural philosophy for thirty years from 1667 to 1697 as a professor. His philosophy specialisation is palpable in his writings, the most important of which is probably Philosophia Naturalis from 1680. It is an essential scientific text, which contains lectures from the University of Padua, in which Rinaldini discusses Galilei's work and experiments and presents his own experiments and discoveries, in particular the discovery of the flow of heat in the air. Other authors whom Rinaldini quotes and argues with are Brahe, Barrow, Borelli, Boyle, Copernicus, Descartes, Gassendi, Kepler, Riccoli, and Torricelli. Rinaldini was an important man of a time marked by the combination of Aristotle's ideas with the ideas of the "new science" of Galileo and his collaborators. ${ }^{21}$

Although no detailed information about Elena Cornaro's philosophical curricula is available, nearly all Renaissance universities based their instruction on corpus aristotelicum. Universities differed in which areas of the corpus were taught: logic was taught everywhere (some institutions emphasised Prior Analytics, others Posterior Analytics, and still others Topics). The philosophy of nature was also often taught, chiefly at medicine-dominated universities (Bologna and Padua). Metaphysics was often a supplementary subject, separate from compulsory examinations (Padua), while in some cases, it was the major subject (Protestant universities). ${ }^{22}$ The University of Padua was known for its specific interpretation of Aristotle (Pietro Pomponazzi, Giacomo Zabarella, Cesare Cremonini, and Carlo Rinaldini); "Padua Aristotelianism" is considered by some authors a specific phenomenon. ${ }^{23}$ This

${ }^{21}$ For more, see William E. K. Middleton, The Experimenters: A Study of the Accademia Del Cimento (Baltimore: The Johns Hopkins Press, 1971).

${ }^{22}$ Heinrich Kuhn, "Aristotelianism in the Renaissance", The Stanford Encyclopedia of Philosophy [online], rev. 28.02.2018. Access 20.04.2020, https://plato.stanford.edu/entries/ aristotelianism-renaissance.

For more on Aristotelianism during the Renaissance, see Charles B. Schmitt, Aristotle and the Renaissance (Cambridge: Harvard University Press, 1983).

23 The first researcher to consider the specific character of Padua Aristotelianism was John H. Randall, The School of Padua and the Emergence of Modern Science (Padua: Editrice Antenore, 1961). A number of authors joined the disputation, of whom some disagree with 
was probably the reason behind the choice of texts for the defence of Elena Cornaro's doctorate, mentioned below in the text.

Early on, at the age of 23, Elena Cornaro was already acclaimed for her outstanding education and abilities, as evident from the fact that members of the learned Accademia dei Ricovrati in Padua approved her as a member as early as 1669 , before she received her doctorate. ${ }^{24}$ In 1677 , her professor of theology, Father Rotondi, acknowledged that Elena Cornaro's knowledge was at such a level that she could apply for a doctorate in theology at the University of Padua. The proposal was approved by the University of Padua, but rejected by the then Cardinal Gregorio Barbarigo, Bishop of Padua, and Chancellor of the University, who thought it unacceptable to award a doctorate in theology to a woman. Elena Cornaro's father strongly objected to the decision, which caused a rift in their hitherto friendly relations. ${ }^{25}$ The parties ultimately reached a compromise - her philosophy teacher Carlo Rinaldini suggested she be awarded a doctorate in philosophy, and the proposal was accepted on the condition that Elena Cornaro would not teach (a university doctorate usually implied teaching at university).

A day before the defence, the commission assigned Elena Cornaro to analyse and argue the following passages from Aristotle:

1) Aristotle: Posterior Analytics, Book 1, Part 2:

"Assuming then that my thesis as to the nature of scientific knowing is correct, the premisses of demonstrated knowledge must be true, primary, immediate, better known than and prior to the conclusion, which is further related to them as effect to cause. Unless these conditions are satisfied, the basic truths will not be 'appropriate' to the conclusion. Syllogism there may indeed be without these conditions, but such syllogism, not being productive of scientific knowledge, will not be demonstration".26

the assumption, for example Charles B. Schmitt, The Aristotelian Tradition and Renaissance Universities (London: Valorium Reprints, 1984).

${ }^{24}$ Francesco L. Maschietto, Elena Lucrezia Cornaro Piscopia (1646-1684), 83.

25 Ibid., 68.

${ }^{26}$ Aristotle, Posterior Analytics, trans. G. R. G. Mure, http://classics.mit.edu/Aristotle/ posterior.1.i.html. 
2) Aristotle: Physics, Book 1, Part 5:

"It is plain then that they all in one way or another identify the contraries with the principles. And with good reason. For first principles must not be derived from one another nor from anything else, while everything has to be derived from them. But these conditions are fulfilled by the primary contraries, which are not derived from anything else because they are primary, nor from each other because they are contraries".7

The public defence of the theses was to take place in the university auditorium, but the attendance was so large that the place of the defence was changed to the nearby Basilica of Saint Anthony, the largest church in Padua. Elena Cornaro defended Aristotle's theses in Latin for more than an hour, and her speech apparently captivated all members of the commission to such a degree that they decided not to vote secretly, as was the custom, but by acclamation (that is publicly). According to Maschietto, Elena asked them to follow the standard procedure and vote secretly, yet the commission voted publicly, unanimously declaring her a doctor of philosophy on the spot. An official awarding ceremony took place the very next day - Elena Cornaro received a book, a ring, an ermine cloak, and a crown of laurel. Two weeks later, she was officially accepted as a member of the Council of Philosophers and Physicians of the University of Padua.

Before defending her doctorate, Elena was offered membership in a host of academies (that is, societies of scholars), from which she carefully chose: she was a member of the Accademia dei Ricovrati, Accademia degli Intronati in Siena, Accademia degli Infecondi in Rome, Accademia dei Dodonei and Accademia dei Pacifici in Venice, Accademia degli Erranti in Brescia. ${ }^{28}$

After defending her doctorate in 1678, she made Padua her home, having lived there already from time to time in a house that belonged to her family. According to Maschietto, the Padua house built by Alvise Cornaro

27 Aristotle, Physics, trans. R. P. Hardie and R. K. Gaye, http://classics.mit.edu/Aristotle/ physics.1.i.html.

${ }^{28}$ For more about the Italian academies, see Italy's Eighteenth Century. Gender and Culture in the Age of the Grand Tour, eds. Paula Findler, Wendy W. Roworth, Catherin M. Sama (Bloomington: Stanford University Press, 2009); The Italian Academies 1525-1700: Networks of Culture, Innovation and Dissent, eds. Jane R. Everson, Denis V. Reidy, Lisa Sampson (Cambridge-Abingdon: Routledge, 2016). 
as one of the first buildings in renaissance style often hosted a group of professors of the University of Padua and other scholars, who were the core of the Accademia dei Ricovrati (present Accademia Galileiana). The society was founded, according to Muir, by twenty-six Venetian and Padua aristocrats and priests, together with Cremonini and Galileo, professors of the University of Padua. ${ }^{29}$ Elena, as indicated above, later became a member of the Accademia dei Ricovrati; the group had therefore initially met in the house where she died a century later.

Little of Elena Cornaro's texts have survived until the present - Elena had allegedly asked her maid to burn all the treatises after her death. The maid kept her promise, so the only texts which are still available are those which were kept by learned societies (four academic debates), the family, or those who received them (letters and poems). Her texts were published posthumously in 1688 in Padua in a work abbreviated as Opera. ${ }^{30}$ The work opens with a short introduction, followed by a preface describing her life (B. Bacchinus, pp. 1-48, both in Latin). The next part consists of the academic texts of Elena Cornaro (three, written in Italian, pp. 51-106, one of them has not been published yet), her elogies (speeches or poems celebrating the king, church dignitaries and others, in Latin, pp. 109-135), and correspondence a series of letters addressed to or sent by her (from important ecclesiastical and secular figures, in Italian and Latin, pp. 139-177). The final part includes her translation of Alloquium Jesu Christi ad animam Fidelem from Spanish into Italian (pp. 181-310).

Her academic disputations were probably written between 1670 and 1672: the first was prepared for the Accademia dei Pacifici in Venice on the occasion of her admission to the institution. It was the answer to whether too much luxury and drinking pose a threat to the Venetian Republic. The second, presented by Elena Cornaro at the same academy upon her election as its President in 1670 , posits that those aspiring to a leading position need to recognise the ensuing responsibility and resist the glamour. The third, which

29 Edward Muir, The culture wars of the Late Renaissance. Sceptics, libertines and opera (Cambridge: Harvard University Press, 2007), 35.

30 Full title: Piscopia, H. L. C. (1688): Helenae Lucretiae (Quae \& Scholastica) Corneliae Piscopiae Virginis Pietatae, \& Eruditione admirabilis, Ordini D. Benedicti Primatis votis adscriptae Opera Quae quidem haberi potuerunt, Parmae. 
she wrote during her presidency, argues that diverse parts can form a harmonious whole. She illustrates the thesis on the human body, where various organs, which she describes in detail, form a harmonious and almost perfect whole and lists three areas of possible "inconsistent consistency": music, astronomy, and theology. Unlike theories of the composition of matter at the time (sulphur, salt, spirit, earth, and water), she adheres to Aristotle's concept of the four elements (fire, water, earth, and air). ${ }^{31}$

Elena Cornaro suffered from various diseases all her life, and her health deteriorated after she defended her doctorate. ${ }^{32}$ Nevertheless, she continued to study and aid the poor. She died in Padua probably of tuberculosis at the age of thirty-eight. She is buried in the Basilica of Santa Giustina in Padua.

\section{A (Non-)Tradition?}

It would seem that Elena Cornaro's success set a precedent, opening the way for other women to a doctorate from the University of Padua. The opposite is true, however. Though, a few months after Elena Cornaro earned her doctorate, Carlo Patin, a professor at the University of Padua, set about applying for a doctorate for his daughter, Carla Patin; the application was not accepted. Maschietto reports that the university officials feared being exposed to applications from women who did not deserve a doctorate. ${ }^{33}$ Another factor was Cardinal Gregorio Barbariga's opposition to women's university education (he consented to Elena Cornaro's application only to compensate for his rejection of her doctorate in theology). He issued a guideline stating that the university "must not admit females under any circumstance to the

31 Maschietto, Elena Lucrezia Cornaro Piscopia (1646-1684), 93-95.

32 As Guernsey reports, she developed symptoms of "holy anorexia", which is starvation for religious reasons. Jane H. Guernsey, The Lady Cornaro, Pride and Prodigy of Venice (Wooster: College Avenue Press, 1999), xi.

33 Interesting enough, Elena Cornaro's father also opposed the application, claiming that Carla Patin was not sufficiently qualified. Should Carla Patin manage to receive the doctorate, he would consider this a threat to the prestige of Elena's doctorate. Maschietto, Elena Lucrezia Cornaro Piscopia (1646-1684), 79-83. 
doctoral degree, nor take steps which lead towards this end without previous notice and agreement by our magistracy". ${ }^{34}$ Although the text did not explicitly ban applications, it definitely impeded the process. ${ }^{35}$

It took another fifty years before another woman, Laura Maria Caterina Bassi (1711-1778), enrolled at university, this time the University of Bologna. Laura Bassi was another child prodigy: she started to learn Latin at the age of five under the guidance of her uncle, Father Lorenzo Stefani, who also taught her French and arithmetic. When she was thirteen, she began studying philosophy with the help of Gaetano Tacconi, a family doctor who taught at the University of Bologna and was a member of the Bologna Academy of Sciences. ${ }^{36}$ Laura Bassi's house hosted regular philosophical disputations, which were also attended by some of the members of the Bologna Academy of Sciences. They were so impressed with Bassi that she was elected a member of this academy with voting rights a month before the public defence of her doctorate. Laura Bassi was also lucky that Cardinal Lambertini, the future Pope Benedict XIV, once attended one of the discussions at her house, and when he saw her talents and abilities, he became her patron and supporter. Laura Bassi received her Doctorate in Philosophy from the University of Bologna in May 1732 after defending 49 theses. The following month she defended another 12 theses, which entitled her to apply for a professorship at this university with the right to teach philosophy. Some of these 61 theses were on physics and other scientific topics. Laura Bassi supported Newton's philosophy and scientific results at a time when the attention of most European scientists was on Descartes and Galen. Although she received the professorship, it was conditioned, due to her gender, by a ban on public teaching unless her superiors called her to do so. They did, from time to time, and Laura Bassi delivered a few lectures at the University of Bologna. She was also paid one

${ }^{34}$ Maschietto, Elena Lucrezia Cornaro Piscopia (1646-1684), 79.

35 As O'Neill writes, "Immediately afterward [after Elena Cornaro was awarded the doctorate], the university agreed to admit no more women". Eileen O’Neill, "Disappearing Ink: Early Modern Women Philosophers and Their Fate in History", in Philosophy in a Feminist Voice: Critiques and Reconstructions, ed. Janet A. Kourany (Princeton: Princeton University Press, 1998), 18.

${ }^{36}$ Gabriela B. Logan, “The Desire to Contribute: An Eighteenth-Century Italian Woman of Science", The American Historical Review 99 (1994): 785-812. Access 21.04.2020, http:// www.jstor.org/stable/2167770. 
of the highest salaries at the university. Bassi joined several learned Italian societies (for example, Accademia Benedettina), where she was accepted as an extra member due to her gender (this academy had a fixed number of 14 members). She became a professor of experimental physics at the Institute of Sciences of the university in 1776 . When she married her colleague Guiseppe Verati, a graduate of philosophy and medicine at the University of Bologna, where he also taught physics, she began teaching students at home. Home tutelage was standard at the time and officially recognised by the Bologna senate in 1665. It was an advantage for Laura Bassi as she did not have to follow the university curriculum, which was still Aristotelian, and she could conduct experiments. Laura Bassi specialised in electricity, chemistry, heat and hydraulics, particularly air and water movement. ${ }^{37}$

Another successful female scientist of the eighteenth century was Maria Gaetana Agnesi, a prominent Italian mathematician who wrote the first mathematics textbook. Mary Agnesi was, like Laura Bassi, supported by Pope Benedict XIV. She was appointed Professor of Mathematics at the University of Bologna in 1750. The position was only an honorary one, and Maria Agnesi never taught at university. The third woman to receive a doctorate in philosophy and mathematics from the University of Bologna was Cristina Roccati in $1751 .^{38}$

The question is whether the seventeenth century brought a fundamental change in the relationship of universities to women as students or whether the "openness" to women is a matter of Italian universities only. What was the situation like for women philosophers in other European countries of the time and why did the seventeenth century see a much higher number of women philosophers in Europe than ever before?

37 For more about Laura Bassi, see Gabriela B. Logan, "The Desire to Contribute: An Eighteenth-Century Italian Woman of Science"; Paula Findler, "Science as a Career in Enlightenment Italy: The Strategies of Laura Bassi", ISIS 84 (1993): 441-469. Access 21.03.2020, http:// www.jstor.org/stable/235642; and Monique Frize, Laura Bassi and Science in 18th Century Europe: The Extraordinary Life and Role of Italy's Pioneering Female Professor (Berlin, Heidelberg: Springer-Verlag, 2013).

${ }^{38}$ Logan, "The Desire to Contribute: An Eighteenth-Century Italian Woman of Science", 802. 
The increased interest of women in philosophy could have been caused by - apart from other important aspects - the change in the understanding of philosophy and its implementation initiated by the thinking of René Descartes. Scholasticism had made it difficult for women to enter philosophical discourse as it required a good command of Latin and the writings of ancient philosophers and church fathers, whose statements were considered an argument in philosophical disputation. These prerequisites, in contrast, were not crucial for René Descartes: instead of drawing on learning generated by previous thinkers, he emphasised the evidence of reason, which, in his opinion, was inherent in varying degrees to all people. Descartes' philosophy was therefore liberating for "lay people" - including women - interested in philosophy: he believed that lack of academic education was not an obstacle to philosophising, rather the opposite as they were not burdened by academic education and respect for authorities. So, women interested in philosophy were encouraged to seek different sources of inspiration and knowledge outside the university, such as salons, public lectures, private laboratories, learned societies, and others available at that time. ${ }^{39}$

Descartes himself highly valued the intellect of Elisabeth of Bohemia (1618-1680) and also Christina, Queen of Sweden (1626-1689). This is clear from Descartes' correspondence with Elizabeth of Bohemia, ${ }^{40}$ and from the fact that Descartes dedicated his opus magnum - Principles of Philosophy to her in 1644. He claimed there that "I have never yet met anyone who understood so generally and so well as yourself all that is contained in my writings". ${ }^{41}$

39 From that aspect, the phenomenon of French salons is an important one. The salons began to emerge in France, in Paris in particular, between 1640 and 1660 as informal places for intellectual disputations on different topics including philosophy; most of them were led by women. For more about this phenomenon, see Amelia G. Mason, The Women of the French Salons, ref. 6.02.2013. Access 20.04.2020, https://www.gutenberg.org/files/2528/2528-h/2528h.htm. For philosophical views of some of the salonnières, see John J. Conley, The Suspicion of Virtue. Women Philosophers in Neoclassical France (Ithaca: Cornell University Press, 2003).

40 See Elisabeth of Bohemia - René Descartes, The Correspondence between Princess Elisabeth of Bohemia and René Descartes, ed. and trans. Lisa Shapiro (Chicago: The University of Chicago Press, 2007). Only the letters from Descartes to Elisabeth have been translated into Czech: René Descartes, Dopisy Alžbětě Falcké, trans. Petr Horák (Brno: Petrov, 1997).

${ }^{41}$ René Descartes, The Principles of Philosophy, trans. from Latin and collated with French by John Veitch. Access 21.03.2020, http://www.fullbooks.com/the-principles-of-philosophy1. html. 
Was Elena Cornaro acquainted with Descartes philosophy? We do not have proof for that, but it is likely to be the case, given that her teacher Carlo Rinaldini was familiar with the work of this philosopher. The main pillar of her education was, however, the theories and methods of philosophical authorities like Aristotle, as implied by her doctorate defence. Elena Cornaro nevertheless pursued a plethora of other sciences, and in this respect, it might be expected that she found herself between scholasticism and the modern age just like her teacher Carlo Rinaldini - an active "experimental" scientist and supporter of Aristotelianism.

Just to mention some of the other women philosophers of the seventeenth century. One of them was Anna Maria van Schurman (1607-1678), whose philosophical style belonged to scholasticism (she was the pupil of Voetius). Anna Maria van Schurman was, like Elena Cornaro, considered a child prodigy, and she was famous in Europe for the breadth of her education and talents. As was mentioned above, she was even allowed to attend lectures at Utrecht University, an unparalleled privilege, although she had to sit behind a curtain so that no one could see her. Like Elena Cornaro, she caused such a stir among the European intellectual elite that they flocked to her house to see her intellectual capacities for themselves and to hold debates with her. Maria van Schurman corresponded with Elizabeth of Bohemia, but the differences in their philosophical thinking, mentioned above, cooled the relationship. They were nevertheless brought together by religion at the end of their lives: Elizabeth sheltered Maria van Schurman in her convent after the latter had to leave Utrecht because of her Labadist religious beliefs. Other philosophers of that time were: Anne Conway (1601-1679), Bathsua Makin (1608?1675?), Margaret Cavendish (1623-1673), Damaris Cudworth Masham (1659-1708), Mary Astell (1666-1731), and Catherine Trotter Cockburn (1679-1749) in England; Juana Inés de la Cruz (1651-1695) in Spain; Marie le Jars de Gournay (1565-1645), Madame de Sévigné (1626-1696) and the founders of the two most renowned French salons of the seventeenth century, Marquise de Rambouillet and Madeleine de Scudéry, Madame Anna Dacier (1654-1720), a well-known expert and translator of ancient poets, namely Homer, in France; Christina of Sweden (1626-1689), a philosopher who invited René Descartes to her court and later abdicated the throne and moved 
to Rome to found and run an intellectual salon. ${ }^{42}$ A great number of contemporaries communicated with each other in writing or in person: Marie van Schurman corresponded with Marie le Jars de Gourney, Batsua Makin, and Elisabeth of Bohemia; Christina of Sweden corresponded with Anne Dacier and visited Maria Schurman. ${ }^{43}$ As the surviving correspondence indicates, Elena Cornaro also corresponded with a host of prominent figures. As for women, she corresponded with another scholar Veronica Malaguzzi Valeri, whose father wanted her to win recognition (and money), but failed at the European courts of the time. ${ }^{44}$

\section{Conclusion}

Elena Cornaro could receive Doctorate in Philosophy from the University of Padua thanks to several factors coinciding, some of which are mentioned above in the text. Her competence, however, did not change the view the then society held regarding the (non) admission of women to university studies; even though Italian universities had been more open to women students from the very beginning, and the University of Padua, in particular, was considered a "heaven of tolerance and liberty". 45

Elena Cornaro was an expert on Aristotelianism, which dominated the curricula of many universities, especially the University of Padua. She combined philosophy with theology and knowledge of science. She was so pious

${ }^{42}$ For more about women philosophers of the $17^{\text {th }}$ century, see Mary Ellen Waithe, A History of Women Philosophers, vol. III; Jacqueline Broad, Women Philosophers of the seventeenth century (Cambridge: Cambridge University Press, 2002); Women Philosophers of the Early Modern Period, ed. Margaret Atherton (Indianapolis: Hackett Publishing Co., 1994); Hypatia's Daughters: Fifteen Hundred Years of Women Philosophers, ed. Linda L. McAlister (Bloomington: Indiana University Press, 1996).

43 Female Scholars. A Tradition Of Learned Women Before 1800, ed. Jeanie R Brink (Montréal: Eden Press Women's Publications, 1980), 1-6.

${ }^{44}$ Maschietto, Elena Lucrezia Cornaro Piscopia (1646-1684), 76.

45 A History of the University in Europe: Volume 2, Universities in Early Modern Europe (1500-1800), ed. Hilde de Ridder-Symoens (Cambridge: Cambridge University Press, 2003), 294. 
that she became a lay sister of the Benedictine order and lived in accordance with its principles. She did not publish her texts in her lifetime (she issued instructions to have them destroyed after her death). On the other hand, Elena Cornaro was a member of several learned societies of Italy and presided over one. Despite delivering a few lectures for the societies, she was not much involved in their activities, perhaps due to her poor health.

According to J. E. Everson and L. Sampson, members of the Accademia degli Infecondi praised Elena Cornaro (in a publication issued on the anniversary of her death) for "her heroic attainment in overcoming the vices characteristic of women, defined as ignoranza (ignorance), superbia (pride), and lusso (vanity or luxury, though with connotations also to sexual immodesty)". ${ }^{46}$ They underlined her singularity; like many other women mentioned in the text, she was considered a child prodigy and, as an adult, one who had transcended her sex. Her case was interpreted in a way that implied that her achievements were beyond the reach of "normal" women, and therefore her example could not apply to women in general. Admiration for the feats of this particular woman thus coexisted with the "gender order" of the time.

Despite all the circumstances, which limited her influence on future developments, several indicators suggest that she may have, after all, contributed to a change of the view of women"s intellectual abilities and their appreciation by academic institutions in the future. Fifty-four years after her death, the University of Bologna awarded Laura Bassi a doctorate in philosophy and allowed her to work as a professor at the university (though teaching mostly at home); Marie Agnesi received the honorary position of professor of mathematics here; the same university awarded the third doctorate in philosophy to Cristina Roccati in 1751. The year Elena Cornaro died, the Accademia dei Ricovrati of Padua admitted Madame Dacier and Madeleine de Scudéry, who had been nominated to the French Academy but suffered rejection; the Academy of Sciences of the Institute of Bologna accepted Emilie du Châtelet as its member in $1746 .{ }^{47}$

46 The Italian Academies 1525-1700: Networks of Culture, Innovation and Dissent, eds. Jane R. Everson, Denis V. Reidy, Lisa Sampson (Cambridge-Abingdon: Routledge, 2016), xv.

${ }^{47}$ Eileen O’Neill, “Disappearing Ink: Early Modern Women Philosophers and Their Fate in History", 18. 
Margaret King agrees with the critical remark Joan Kelly made in 1977: "there was no 'renaissance' for women, at least not during the Renaissance". 48 Yet, she believes that: "Something changed during the Renaissance in women's sense of themselves, even if very little changed or changed for the better in their social condition. The change did have its roots in the spiritual experience of women, and it culminates in the consciousness put into words by the first feminists of the Renaissance. Not monsters, not defects in nature, but the intelligent seekers of a new way, these women wielded the picks of their understanding to build a better city for ladies". ${ }^{9}$ One of the pieces in this puzzle is the life story of Elena Cornaro, whose journey - the study of philosophy, theology, and science, crowned with a doctorate from the University of Padua - contributed to expanding the space for women's self-realisation.

\section{References}

Agonito Rosemary (ed.). 1977. History of Ideas on Woman: A Source Book. New York: G. P. Putnam's Sons.

Albisetti James C., Joyce Goodman, Rebecca Rogers (eds.). 2010. Girls' Secondary Education in the Western World: From the 18th to the 20th Century. New York: Palgrave Macmillan.

Aquinas Thomas. 1912. Summa Theologica, trans. Fathers of the English Dominican Province. Access 22.03.2020. https://www.documentacatholicaomnia.eu /03d/1225-1274,_Thomas_Aquinas,_Summa_Theologiae_\%5B1\%5D,_EN.pdf. Aristotle. On the Generation of Animals, Bks. I, II. Access 22.03.2020. http://www.esp. org/books/aristotle/generation-of-animals/index.html.

Aristotle. On the History of Animals, Bk. IX. Access 22.03.2020. http://www.esp.org/ books/aristotle/history-of-animals/index.html.

Aristotle. Physics, transl. R. P. Hardie and R. K. Gaye. Access 21.03.2020. http://classics.mit.edu/Aristotle/physics.1.i.html.

48 Joan Kelly-Gadol, "Did Women Have a Renaissance?", in Becoming Visible: Women in European History, eds. Renate Bridenthal, Claudia Koonz (Boston: Houghton Mifflin Co, 1977), 139.

49 Margaret L. King, Women of the Renaissance (Chicago: University of Chicago Press, 1991), 238-239. 
Aristotle. Politics, trans. Benjamin Jowett. Access 22.04.2020. http://classics.mit.edu/ Aristotle/politics.1.one.html.

Aristotle. Posterior Analytics, trans. Geoffrey R. G. Mure. Access 21.03.2020. http:// classics.mit.edu/Aristotle/posterior.1.i.html.

Atherton Margaret (ed.). 1994. Women Philosophers of the Early Modern Period. Indianapolis: Hackett Publishing Co.

Brink Jeanie R. (ed.). 1980. Female Scholars. A Tradition Of Learned Women Before 1800. Montréal: Eden Press Women's Publications.

Broad Jacqueline. 2002. Women Philosophers of the seventeenth century. Cambridge: Cambridge University Press.

Castiglione Baldassare. 2003. The Book of the Courtier, transl. Leonard Eckstein Opdycke. New York: Dover Publications.

Chojnacki Stanley. 1991. "The Most Serious Duty: Motherhood, Gender, and Patrician Culture in Renaissance Venice". In Refiguring Woman: Perspectives on Gender and the Italian Renaissance, eds. Marylin Migiel, Juliana Schiesari, 133-154. Ithaca: Cornell University Press.

Chojnacki Stanley. 2000. Women and Men in Renaissance Venice: Twelve Essays on Patrician Society. Baltimore: Johns Hopkins University Press. Conley John J. 2003. The Suspicion of Virtue. Women Philosophers in Neoclassical France. Ithaca: Cornell University Press.

De Pizan Christine. 2000. The Book of the City of Ladies, trans. Rosalind Brown-Grant. London: Penguin Classics.

Descartes René. 1997. Dopisy Alžbětě Falcké, trans. Petr Horák. Brno: Petrov.

Descartes René. The Principles of Philosophy, transl. from Latin and collated with French by John Veitch. Access 21.03.2020. http://www.fullbooks.com/the-principles-of-philosophy1.html.

Duni Matteo. 2008. Under the Devil's Spell: Witches, Sorcerers, and the Inquisition in Renaissance Italy. New York: Syracuse University Press.

Elisabeth of Bohemia - Descartes René. 2007. The Correspondence between Princes Elisabeth of Bohemia and René Descartes, ed. and trans. Lisa Shapiro. Chicago: The University of Chicago Press.

Everson Jane R., Denis V. Reidy, Lisa Sampson (eds.). 2016. The Italian Academies 1525-1700: Networks of Culture, Innovation and Dissent. Cambridge-Abingdon: Routledge.

Findler Paula. 1993. "Science as a Career in Enlightenment Italy: The Strategies of Laura Bassi”. ISIS 84, 3: 441-469. Access 21.03.2020. http://www.jstor.org/stable/235642.

Findler Paula, Wendy W. Roworth, Catherin M. Sama (eds.). 2009. Italy's Eighteenth Century. Gender and Culture in the Age of the Grand Tour. Bloomington: Stanford University Press. 
Frize Monique. 2013. Laura Bassi and Science in 18th Century Europe: The Extraordinary Life and Role of Italy's Pioneering Female Professor. Berlin, Heidelberg: Springer-Verlag.

Guernsey Jane H. 1999. The Lady Cornaro, Pride and Prodigy of Venice. Wooster: College Avenue Press.

Kalnická Zdeňka. 2009. "Genderovanost filozofického kánonu a textové 'strategie' marginalizace filozofek”. Sociologický časopis/Czech Sociological Review 45, 4. 809-833.

Kelly-Gadol, Joan. 1977. “Did Women Have a Renaissance?”. In Becoming Visible: Women in European History, eds. Renate Bridenthal, Claudia Koonz, 137-164. Boston: Houghton Mifflin Co.

King Margaret L. 1991. Women of the Renaissance. Chicago: University of Chicago Press.

Kuhn Heinrich. "Aristotelianism in the Renaissance". In The Stanford Encyclopedia of Philosophy [online], rev. 28.02.2018. Access 20.04.2020. https://plato.stanford. edu/entries/aristotelianism-renaissance.

Laertios Diogenés. 2018. Lives of the Eminent Philosophers, trans. Pamela Mensch. Oxford: Oxford University Press.

Lloyd Geneviève. 1984. The Man of Reason. "Male" and "Female" in Western Philosophy. Minneapolis: University of Minnesota Press.

Logan Gabriela B. 1994. "The Desire to Contribute: An Eighteenth-Century Italian Woman of Science". The American Historical Review 99, 3: 785-812. Access 21.04.2020. http://www.jstor.org/stable/2167770.

Martin John J., Dennis Romano D. (eds.). 2002. Venice Reconsidered: The History and Civilisation of an Italian City-State, 1297-1797. Baltimore: The Johns Hopkins University Press.

Maschietto Francesco L. 2007. Elena Lucrezia Cornaro Piscopia (1646-1684) - The First Woman in the World to Earn a University Degree. Philadelphia: Saint Joseph's University Press.

Mason Amelia G. The Women of the French Salons, ref. 6.02.2013. Access 20.04.2020, https://www.gutenberg.org/files/2528/2528-h/2528-h.htm.

McAlister Linda L. (ed.). 1996. Hypatia's Daughters: Fifteen Hundred Years of Women Philosophers. Bloomington: Indiana University Press.

Ménage Gilles. 1984. The History of Women Philosophers, trans. Beatrice H. Zedler. Lanham: University Press of America.

Middleton William E. K. 1971. The Experimenters: A Study of the Accademia Del Cimento. Baltimore: The Johns Hopkins Press.

Muir Edward. 2007. The culture wars of the Late Renaissance. Sceptics, libertines and opera. Cambridge: Harvard University Press.

Norwich, John J. 1971. A History of Venice. London: Vintage. 
O’Neill Eileen. 1998. "Disappearing Ink: Early Modern Women Philosophers and Their Fate in History". In Philosophy in a Feminist Voice: Critiques and Reconstructions, ed. Janet A. Kourany, 17-62. Princeton: Princeton University Press.

Piscopia, H. L. C. 1688. Helenae Lucretiae (Quae \& Scholastica) Corneliae Piscopiae Virginis Pietatae, \& Eruditione admirabilis, Ordini D. Benedicti Primatis votis adscriptae Opera Quae quidem haberi potuerunt. Parmae.

Plato. 2003. The Symposium, trans. Christopher Gill. New York: Penguin.

Randall John H. Jr. 1981. The School of Padua and the Emergence of Modern Science. Padova: Editrice Antenore.

Ridder-Symoens Hilde de (ed.). 2003. A History of the University in Europe: Volume 2, Universities in Early Modern Europe (1500-1800). Cambridge: Cambridge University Press.

Rousseau Jean-Jacques. 1979. Emile, or On Education, trans. Allan Bloom. New York: Basic Books.

Schmitt Charles B. 1983. Aristotle and the Renaissance. Cambridge: Harvard University Press.

Schmitt Charles B. 1984. The Aristotelian Tradition and Renaissance Universities. London: Valorium Reprints.

Seitz Jonathan. 2011. Witchcraft and Inquisition in Early Modern Venice. Cambridge: Cambidge University Press.

Sperling Jutta G. 2000. Convents and the Body Politics in Late Renaissance Venice. Chicago: The University of Chicago Press.

Tuana Nancy. 1993. The Less Noble Sex. Scientific, Religious, and Philosophical Conceptions of Woman's Nature. Bloomington and Indianapolis: Indiana University Press.

Waithe Mary E. (ed.). 1987. A History of Women Philosophers. Volume I. Dordrecht: Kluwer Academic Publishers.

Waithe Mary E. (ed.). 1989. A History of Women Philosophers. Volume II. Dordrecht: Kluwer Academic Publishers.

Waithe Mary E. (ed.). 1991. A History of Women Philosophers. Volume III. Dordrecht: Kluwer Academic Publishers.

Waithe Mary E. (ed.). 1994. A History of Women Philosophers. Volume IV. Dordrecht: Kluwer Academic Publishers. 